\title{
Isolation and Characterization of Lactic Acid Bacteria (Lactobacillus sp.) From Sauerkraut
}

\author{
Resti Fevria ${ }^{1 *}$ Indra Hartanto ${ }^{1}$ \\ ${ }^{1}$ Biology Department Math and Natural Science FacultyPadang State University Padang, Indonesia \\ *Corresponding author. restifevria.rf@gmail.com
}

\begin{abstract}
Sauerkraut is fermented product based on cabbage with the addition of 2.5 percent salt. Sauerkraut can last a long time and has a pretty acidic taste, this is caused by lactic acid bacteria that form during fermentation. Fermentation is a part of biotechnology that uses microorganisms as the main actors in a process. One of the microbes that determines the success of fermentation is lactic acid bacteria. The purpose of this study is to isolate LAB from Sauerkraut, the type of LAB produced microscopically. Research methods, the ingredients used are cabbage fermentation (sauerkraut), $\mathrm{MRSa}, 0.9 \% \mathrm{NaCl}$, crystal violet paint from biological laboratories UNP. LAB isolation from Sauerkraut done in fermentation with Sauerkraut and then plant the sauerkraut into the MRSa medium with streak plate methods. The isolates obtained were identified microscopically using a microscope with gram staining method. From the research that has been done, the following result are Obtained: Sauerkraut direcly into MRSA medium and gram staining, there were 17 colonies of gram-positive bacteria with bacil cell form, and negative catalase test. We can identify these colonies as Lactobacillius sp.

Keywords: Isolation, Sauerkraut, Lactic Acid Bacteria, Lactobacillus sp.
\end{abstract}

\section{INTRODUCTION}

Sauerkaraut is a product of fermentation with the material basis of cabbage, with the addition of salt $2.5 \%$. Sauerkraut is fermented by various bacteria acid lactate, such as Leuconostoc, Lactobacillus and Pediococcus. Sauerkraut can last a long time and has a flavor that is quite sour, matter is caused by bacteria acid lactate which is formed at the time of fermentation. At the moment the process of fermentation should be noted conditions are required microbes in doing the process of metabolism, conditions which are needed in the fermentation of sauerkraut is anaerobic, with medium liquid with the process closed. Fermentation in the manufacture of Sauerkraut is fermented sour Lactate. Bacteria acid lactate is a bacterium which is ordinary used in the manufacture of probiotics.

Lactic acid bacteria (LAB) are Gram-positive bacteria that are rod-shaped or round, do not form spores, facultative anaerobic fermentation, do not have cytochromes, do not have the ability to reduce nitrates and utilize lactate, negative oxidation, negative catalase, negative motility and the ability to ferment glucose to lactic acid ${ }^{[1]}$.

The most important characteristic of lactic acid bacteria is its ability to remodel complex compounds into simple compounds so that lactic acid is produced. These properties are important in the manufacture of fermented products including silage. Acidic products cause stunted growth of other microbes. Pathogenic bacteria such as Salmonella and Staphylococcus aureus found in an ingredient will be inhibited if there is lactic acid bacteria in the material ${ }^{[2]}$.

At present, some lactic acid bacteria that have been successfully isolated from fermented foods include strawberries ${ }^{[3]}$, yellow passion fruit ${ }^{[4]}$ and unggu passion fruit ${ }^{[5]}$, tomatoes ${ }^{[6]}$. Based on the above, the study was conducted, Isolation of Lactic Acid Bacteria (Lactobacillus $s p$ ) from Sauerkraut with the addition of cayenne pepper.

\section{MATERIAL AND METHODS}

This research was conducted at the Biology Laboratory of UNP in August - September 2019, with the procedure:

\subsection{Materials and Equipment}

Research is using the object cabbage and chili pepper that is purchased from the market town of Padang Panjang. Then the material is fermented with the addition of salt 2 , $5 \%$ and $2.5 \%$ cayenne pepper. Section which will study is the result of fermentation are known with sauerkraut. And the medium used is Medium de Men Rogrosa Sharpe (MRS) in order to Marks, $\mathrm{NaCl} 0.9 \%$ solution of $\mathrm{H} 2 \mathrm{O} 2$ $3 \%$, crystal violet paint, paint Lugol iodine, alcohol $96 \%$ and safranin were obtained from the Laboratory of Biological Science Faculty Universitas Negeri Padang.

Tools that are used in research this is a jar, blade cutter, scales analytic, pumpkin measuring, flask Erlenmeyer, saucer dish, incubators, laminar air flow, autoclaves, glass objects , hot plate, tweezers , Bunsen, cup porcelain , spatula metal, ose scratch, rack tubes, microscopes . 


\subsection{Research Implementation}

Sample Preparation (Sauerkaraut Manufacturing)

The process of making sauerkaraut includes:

a. Material preparation and sorting is to choose cabbage

b. Wash with running water and clean

c. Cabbage liver is removed and the leaves are taken

d. Cut cabbage leaves with a size of approximately $0.5 \mathrm{~cm}$

e. Weighing

f. Mixing until $2.5 \%$ salt, chillies

g. The result of mixing is put into a fermentation jar then pressed gently until the water comes out and covers the entire surface of the media (pieces of cabbage)

h. If the water is not much, it can be loaded so that it can cover the entire surface of the media flat.

i. The jar is closed tightly

j. Fermentation in $37^{\circ} \mathrm{C}$ for 3 days

k. The results of fermentation (sauerkraut) are then analyzed.

\subsection{Planting Samples}

Planting of samples can be done by the way, sterilizing the surface of a sample which was cut in an aseptic, and then inserted into a jar that has been sterilized and covered with aluminum foil and dinkubasi for 5 days. After it directly distreak right medium MRS with the use of a needle loop. After the incubation is completed followed by isolating koloni- colonies which grew respectively by differences in the morphology of colonies of bacteria in the dish petri each quadrant. Do isolation to be obtained isolate or colony sole of each dish petri.

\subsection{Identification of Lactic Acid Bacteria $(\mathrm{LAB})$}

Isolates were obtained were identified by the method of macroscopic, to see directly the morphology of isolates of bacteria that grow on the medium include the shape and color of the bacteria. And methods of microscopy by using a microscope with a method of staining gram. Staining gram carried out by applying the bacteria over the object glass, difikasasi then spilled paint gram A, let stand for 1 minute, spilled paint gram B, let stand for 1 minute, spilled paint gram C, let stand for 30 seconds, drops of paint grams of $\mathrm{D}$, let stand 2 minutes. Then covered with a glass cover and drops with emersion oil and then observed the shape and color of cells.

\subsection{Catalase Test}

Test catalase is a test of the bacterium certain whether the bacterium that is bakt eri aerobic, anaerobic facultative, or anaerobic facultative, how are 1) taking cultures of bacteria. 2) Drop one drop of $\mathrm{H}_{2} \mathrm{O}_{2}$ into bacterial culture 3) Observe until there is a bubble or not.

\section{RESULT AND DISCUSSION}

\subsection{Result}

Isolation of Lactic Acid Bacteria (LAB)

Isolation bacteria acid lactate of sauerkraut successfully performed. Bacteria that grow show their colonies are colored white milk, and has a zone of halo that grew after the incubation at a temperature of $37{ }^{\circ} \mathrm{C}$ with time to grow an average of 40 hours. Classification of lactic acid bacteria in different genera is based largely on differences in morphology, ways of fermenting glucose, growth at different temperatures, and configuration of lactic acid produced, the ability to grow at high salt concentrations, and tolerance to acids or bases ${ }^{[7]}$. Special characteristics of lactic acid bacteria are able to grow at high levels of sugar, alcohol, and salt, able to ferment monosaccharides and disaccharides ${ }^{[8]}$.

Fermentation of sauerkraut is fermented in nature are conducted without the addition of microbes from the outside (starter) and occurs with naturally with the help of microflora indigen. Carl (1971) says that the characteristics of the process of this is the presence of bacteria acid lactic that included bacterial heterofermentatif ${ }^{[8]}$. Heterofermentative bacteria: glucose fermented in addition to producing lactic acid also produces other compounds namely ethanol, acetic acid and $\mathrm{CO}_{2}$. Hexose is fermented into lactic acid, carbon dioxide, and ethanol (or acetic acid as an alternative electron acceptor). Pentose is then converted to lactic acid and acetic acid. Example: Leuconostoc and some spesies Lactobacillus.

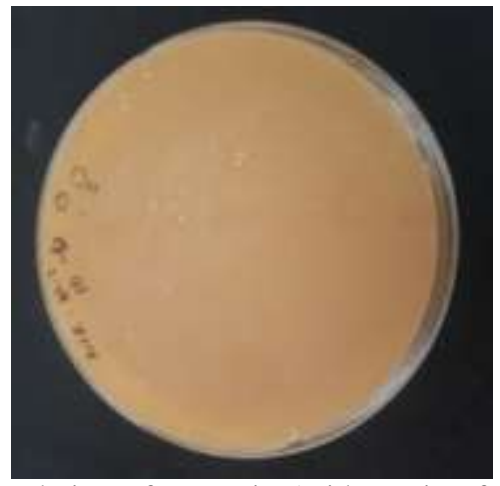

Figure 1. Isolation of Bacteria Acid Lactic of Sauerkraut observation 36 hours of dilution of $10^{6}$ to the medium

Based on the images above bacteria acid lactate which can be isolated 17 colonies. Lactic acid bacteria are isolated to produce antimicrobials that can be used as probiotics. Lactic acid bacteria are bacteria that are commonly used as probiotics. These bacteria are nonpatogenic, nontoxicogenic, Gram positive, anaerobic, do not produce spores, lactic acid producing bacteria produced from carbohydrate fermentation ${ }^{[9]}$.

The most important characteristic of lactic acid bacteria is its ability to remodel complex compounds into simple compounds so that lactic acid is produced. These properties are important in the manufacture of fermented 
products including silage. Acidic products cause stunted growth of other microbes. Pathogenic bacteria such as Salmonella and Staphylococcus aureus found in an ingredient will be inhibited if there is lactic acid bacteria in the material ${ }^{[10]}$.

\subsection{Identification of Isolated Isolates}

\subsubsection{Gram staining}

Results of staining gram on isolates of bacteria sauerkraut is positive, i.e. the cells of bacteria colored purple as do stain gram. The results of gram staining test on isolates resulted in several isolates which have a morphological form of stem cells with a chain arrangement, and it is suspected that this isolate is the genus Lactobacillus. BAL is a group of Gram-positive bacteria in the form of cocci or stems, not forming spores. Special characteristics of Table 1. Gram staining result (gram +) Gram staining

\begin{tabular}{|l|l|l|l|}
\hline $\begin{array}{l}\text { Isolate } \\
\text { code }\end{array}$ & $\begin{array}{l}\text { Morphology of the } \\
\text { colony }\end{array}$ & Image of a colony & Gram staining +/- \\
\hline S. & $\begin{array}{l}\text { Shape: round } \\
\text { Edge: slippery } \\
\text { Elevation: flat } \\
\text { Color: milky white } \\
\text { Medium size }\end{array}$ & & \\
& & & $\begin{array}{l}\text { Gram: Positive } \\
\text { Cell shape: Bacillus }\end{array}$ \\
\hline
\end{tabular}

Characteristics of bacterial gram positive is homogeneous and thick, and most large composed of peptidoglycan, polsakarida other and sour teikoat can participate construct the walls of the cell. The shape of a round cell, stem or filament. Bacteria gram positive is the bacteria that maintain the substance of color crystal violet during the process of coloring grams so it will be colored blue or purple under the microscope

\section{CONCLUSION}

Isolates bacteria acid lactate of sauerkraut have characteristics in macroscopic which forms a round, edge smooth, elevation raised the color of white milk and a size small. The results of the identification of bacterial acid lactate of sauerkraut is a bacterium gram $\mathrm{p}$ ositif to form cell bacill, from staining gram and kat alase negative of test catalase.

\section{REFERENCES}

[1] Carr, FJ, D. Chill, and N. Maida. 2002. The Lactic Acid Bacteria: A Literature Survey. Crit Rev. Microbiol

[2] [2] Mishra, S.K., Sangwan N. S and Sangwan lactic acid bacteria are able to grow at high levels of sugar, alcohol, and salt, able to ferment monosaccharides and disaccharides ${ }^{[11]}$.

In gram staining cells that cannot release color and will remain colored like the color of violet crystals ie bluepurple are called Gram-positive bacteria. Whereas cells that can release violet crystals and bind safranin so that they are pink are called gram-negative bacteria ${ }^{[12]}$.

The principle of gram staining is the ability of cell walls to bind to basic dyes (violet crystals) after washing with $95 \%$ alcohol. This situation is related to the composition of the compounds making up the cell wall. Gram positive bacteria contain more peptidoglycan and less fat than gram negative bacteria ${ }^{[13]}$. BAL morphology of gram staining results can be seen in Table 1 .

\subsubsection{Catalase Test}

Test catalase is done by dropping hydrogen peroxide $\left(\mathrm{H}_{2}\right.$ $\left.\mathrm{O}_{2}\right) 3 \%$ on glass objects were clean. Culture smeared on glass objects that have been dripped with hydrogen peroxide. The suspension was mixed by gently using the OSE. Results negative marked with no formation of bubbles of gas. Results of the test of catalase in 17 isolates of bacteria menunjukaan results negative were shown with no presence of bubbles of gas that contains oxygen as isolated drops of the solution of $\mathrm{H}_{2} \mathrm{O}_{2}$. It is in accordance with research Stamer (1979) which says that the bacteria acidic lactic including bacteria with catalase negative.

R.S. 2007. Andrographis paniculata (Burm. F.) Nees (Kalmegh): Review. Pharmacognosy Review. Vol. 1, Issue2, Jul-Dec 2007.

[3] Fevria, Resti. Hartanto, I. 2018 Isolation and Characterization of Lactic Acid Bacteria (Lactobacillus $s p$ ) from Tomato . EJurnal.UNP.Biosience

[4] Sari, Yuni et al. 2013. Isolation, Characterization and Identification of Lactic Acid Bacteria DNA (BAL) which has the potential as an antimicrobial from Yellow Passion Fruit fermentation. Journal of Chemistry at Andalas University Vol.2 No.2

[5] Zahro Fatimatuz. 2014. Isolation and Identification of Lactic Acid Bacteria from Purple Passion Fruit Fermentation as a producer of exopolysaccharide, Department of Biology, 
Faculty of Science and Technology, University of Maulana Malik Ibrahim Malang.

[6] Fevria, Resti. Hartanto, I. 2019 Isolation and Characterization of Lactic Acid Bacteria (Lactobacillus sp) from Sauerkraut with the addition of Cayenne Pepper . EJurnal.UNP.Biosience

[7] Carl, SP 1971. Microbiology and Food Fermentation. The AVI Publishing Company Inc.Connecticut.

[8] Fevria, Resti. Hartanto, I. 2019 Isolation and Characterization of Lactic Acid Bacteria (Lactobacillus sp) from Strawberry (Fragaria vesca ). Proceedings of the Icomset International Seminar . https://iopscience.iop.org/issue/17426596/1317/1.

[9] Fuller, R. 1989. Probiotics in Man and Animals. Journal Application of Bacteriol. Vol.66. No. 1: 365-378.

[10] Malik, et al. 2008. Glucosiltranferase (GTF) Gene Screening and Exopolisaccharideproducing Lactic Acid-Producing Bacteria, Makara Sains. Vol.12 No.1: 1-6.

[11] Pelczar, MJ, and ECS Chan. 1986. Basic Fundamentals of Microbiology 2. Translated by Hadioetomo RS, Imas T, Tjitrosomo SS, Figures SL. Jakarta: University of Indonesia Publishers. things: 489-522.

[12] Sneath, PHA, NS Mair, ME Sharpe, and JG Holt. 1986. Bergey's Manual of Systematic Bacteriology. Vol 2. Baltimore: Williams and Wilkins.

[13] Stamer, JR 1979. The Lactic Acid Bacteria: Microbe of Diversity. Journal of Food Technology. 33 (1): 60 - 65. 